KS. GRZEGORZ LESZCZYŃSKI

Wydział Prawa i Administracji

Uniwersytetu Łódzkiego

\title{
WYKLUCZENIE JEDNOŚCI MAŁŻEŃSKIEJ JAKO TYTUŁ NIEWAŻNOŚCI MAŁŻEŃSTWA W PROCESIE BISKUPIM
}

Treść: - 1. Proces skrócony czyli biskupi. - 2. Przymiot jedności małżeńskiej. - 3. Wykluczenie jedności małżeńskiej. - 4. Dowody. - 5. Causa simulandi. - Wnioski.

Promulgowany 8 września 2015 r. List apostolski motu proprio Ojca Świetego Franciszka Mitis Iudex Dominus Iesus reformujący kanony Kodeksu Prawa Kanonicznego dotyczące spraw o orzeczenie nieważności małżeństwa nie tylko ma na względzie zagwarantowanie właściwego funkcjonowania sprawiedliwości w Kościele, ale przede wszystkim wychodzi naprzeciw potrzebie uproszczenia procedury orzekania nieważności małżeństwa, przy zagwarantowaniu ochrony jedności w wierze i w dyscyplinie dotyczącej małżeństwa ${ }^{1}$.

\section{Proces skrócony czyli biskupi}

Proces skrócony, stanowiący najbardziej nowatorskie założenie reformy Papieża Franiszka, stanowi największe wyzwanie dla trybunałów kościelnych. Nie wnikając w szczegóły postępowania należy jedynie zauważyć, że proces ten miał być przeprowadzony po

\footnotetext{
${ }^{1}$ Por. Papież Franciszek, List apostolski Mitis Iudex Dominus Iesus reformujacy kanony Kodeksu Prawa Kanonicznego dotyczace spraw o orzeczenie nieważności małżeństwa (tekst łacińsko-polski), Tarnów 2015, s. 9.
} 
spełnieniu, w ocenie wikariusza sądowego ${ }^{2}$, dwóch podstawowych warunków: żądanie zostało zgłoszone przez obydwoje małżonków lub przez jednego z nich za zgodą drugiego; przytaczane są okoliczności dotyczące faktów lub osób, poparte zeznaniami lub dokumentami, które nie wymagają przeprowadzenia dokładniejszego badania albo dochodzenia oraz w sposób oczywisty wskazują na nieważność (kan. 1683 MIDI). W przemówieniu skierowanym do uczestników kursu zorganizowanego przez Trybunał Roty Rzymskiej z dnia 25 listopada 2017 r. Papież Franciszek stwierdza jednak, że skarga winna być zawsze skierowana bezpośrednio do biskupa diecezjalnego ${ }^{3}$. W każdym razie możliwość zastosowania procesu skróconego wydaje się zatem być oczywista jedynie w sytuacjach oczywistych. Praktyka jednak wskazuje, że w niewielu tak naprawdę sprawach oczywistość faktów, zwłaszcza na początkowym etapie postępowania, jest jednoznaczna. Nie wykluczając jednak takiej możliwości należy zauważyć, że istnieje jeszcze drugi warunek istotny, a mianowicie zgodność obojga małżonków, co w procesach kościelnych występuje w mniejszości przypadków.

W sytuacji, gdy zebrany materiał dowodowy nie przekona biskupa diecezji do wydania wyroku pro nullitate sprawa jest kierowana przez biskupa diecezji do postępowania zwyczajnego. Troska Papieża Franciszka dotyka jednak nie kwestii czysto proceduralnych, ale ze względu na szybkość procesu skróconego odnosi się do gwarancji poszanowania zasady nierozerwalności małżeństwa. Sam Papież bowiem stwierdza: „Nie umknęło jednak mojej uwadze, jak bardzo postępowanie skrócone może zagrozić zasadzie nierozerwalności małżeństwa"4. Ta świadomość skłania Papieża do określenia wyłącznej kompetencji biskupa diecezji do orzekania w procesie skróconym, gdyż tylko

\footnotetext{
${ }^{2}$ Por. kan. $1676 \$ 2$ MIDI.

${ }^{3}$ Francesco, Discorso del Santo Padre Francesco ai partecipanti al Corso promosso dal Tribunale della Rota Romana, 25 novembre 2017 https://w2.vatican.va/content/ francesco/it/speeches/2017/november/documents/papa-francesco_20171125_corso-rotaromana.html, n. 5.

${ }^{4}$ Papież Franiszek, List apostolski..., s. 13.
} 
„biskup ${ }^{5}$, który mocą swego zadania pasterskiego daje największą gwarancję katolickiej jedności z Piotrem w wierze i dyscyplinie".

\section{Przymiot jedności małżeńskiej}

Prawodawca w kan. $1056 \$ 2$ KPK wskazuje na dwa istotne przymioty małżeństwa, którymi są jedność i nierozerwalność. Przymiot jedności małżeńskiej (unitas) polega na związku jednego mężczyzny $\mathrm{z}$ jedną kobietą. Oznacza to, że wielożeństwo równoczesne jest zaprzeczeniem przymiotu jedności. Jest nie tylko sprzeczne z prawem natury, ale zakazane prawem ustanowionym przez Chrystusa ${ }^{7}$.

Wielożeństwo posiada różne formy. Poliandria, która polega na związku małżeńskim jednej kobiety z kilkoma mężczyznami jest przede wszystkim zaprzeczeniem pierwszego celu małżeństwa czyli zrodzenia potomstwa, gdyż nie tylko powoduje niepewność ojcostwa, ale zakłóca spokój rodziny i przeszkadza w należytym wychowaniu potomstwa ${ }^{8}$. Poligynia, czyli związek małżeński jednego mężczyzny z kilkoma kobietami, niweczy drugorzędny cel małżeństwa, wzajemną pomoc i uśmierzenie namiętności'. To oznacza, że związek monogamiczny sprzyja nie tylko wychowaniu potomstwa, ale też ułatwia życie rodzinne i realizację celów małżeństwa. Warto zauważyć,

\footnotetext{
${ }^{5} \mathrm{~W}$ założeniach do reformy procesu użyty jest termin „biskup”, choć należy przez to rozumieć biskupa diecezjalnego, gdyż taki termin istnieje w przepisach poszczególnych kanonów odnoszących się do procesu skróconego (np. kan. 1687 $\S 1$ MIDI). Co więcej w przytaczanym już przemówieniu Ojca Świetego Franiszka z dnia 25 listopada 2017 r. stwierdza się jednoznacznie: „Il Vescovo diocesano in forza del suo ufficio pastorale è giudice personale ed unico nel processo breviore" (Francesco, Discorso..., dz. cyt., n. 1).

${ }^{6}$ Papież Franciszek, List apostolski..., s. 13.

${ }^{7}$ Por. F. BĄczkowicz, Prawo kanoniczne, t. II, Kraków 1933, s. 45.

${ }^{8}$ Por. F. CApello, Tractatus canonico-moralis de Sacramentis, Romae 1923, s. 11. Jak pisze autor: „Polyandria absolute repugnat iuri naturae, quia positive exclusit omnes fines matrimonii, non solum secundarium, sed etiam primarium”.

${ }^{9}$ Por. tamże. Ponownie F. CAppello: „Polygamia proprie dicta seu polygynia non repugnat absolute iuri naturae, i. e. primis eius praeceptis, sed generatim a iure naturae reprobatur, utpote repugnans secundis legis naturalis praeceptis, et ideo fini matrimonii secundario".
} 
iż jedności małżeńskiej sprzeciwia się jedynie wielożeństwo równoczesne, nie zaś kolejne ${ }^{10}$.

Nauka katolicka uznaje małżeństwo monogamiczne za właściwe naturze ludzkiej. Z takim małżeństwem spotykamy się u ludów pierwotnych. Potrzebę monogamii uzasadnia bardzo jednoznacznie nauczanie Chrystusa i św. Pawła. Chrystus, co prawda nie mówi wprost o monogamii, ale jego nauka dotycząca nierozerwalności małżeństwa pozwala przyjąć, iż potępia on poligamię odrzucając zresztą inne praktyki starotestamentalne. Monogamia obecna jest w sposób jednoznaczny w nauczaniu Kościoła, zaś Sobór Trydencki uznaje ją za prawdę wiary ${ }^{11}$.

\section{Wykluczenie jedności małżeńskiej}

Najstarszą historyczną formą wykluczenia jedności węzła, inspirowaną kulturą, która dyskryminowała wartość jednej płci człowieka, jest poligamiczna wola małżeńska. Jak zauważa P. J. Viladrich, poligamia dyskryminowała najczęściej kobietę $\mathrm{w}$ formie poligynii, oznaczającej związek jednego mężczyzny z kilkoma kobietami, gdyż poliandria, a więc związek jednej kobiety z kilkoma mężczyznami, była historycznie bardzo rzadka ${ }^{12}$.

\footnotetext{
${ }^{10}$ Por. F. Bączkowicz, dz. cyt., s. 45; F. X. Wernz, Ius Decretalium, t. IV, Prati 1912, s. 30-31. Jak pisze F. Wernz: „Unitas importat ut matrimonium sit coniugium unis cum una in individua societate ad fines matrimonii proprios et excludit polyandriam et polygyniam. Utraque proinde repugnat iuri naturali quamvis diverso modo; nam polyandria repugnat absolute, cum opponantur primis principiis iuris naturalis utpote excludens omnes matrimonii fines, non solum secundarium, sed etiam primarium; polygynia vero, quae praesertim intelligitur sub nomine polygamiae etiam a iure naturali reprobatur, quippe saltem secundariis legis naturalis principiis repugnat utpote saltem secundarios matrimonii fines ex communiter contingentibus excludens, absolute vero iuri naturae seu primis iuris naturalis principiis non omnino repugnat”.

${ }^{11}$ Por. S. Biskupski, Prawo małżeńskie Kościoła rzymskokatolickiego, t. I, Warszawa 1956, s. 47-49.

${ }^{12}$ Por. P. J. VILADRICH, Konsens małżeński. Sposoby prawnej oceny i interpretacji w kanonicznych procesach o stwierdzenie nieważności małżeństwa, Warszawa 2000, s. 329.
} 
Wola poligamiczna oznacza pozytywną, aktualną albo witualną i nie odwołaną wolę jednego lub obojga kontrahentów zarezerwowania sobie prawa zawarcia innego nowego węzła małżeńskiego, przy jednoczesnym trwaniu pierwszego węzła. Stąd wola poligamiczna jest wolą skierowaną przeciw wyłączności węzła małżeńskiego ${ }^{13}$.

Wola konkubencka polega na zastrzeżeniu sobie prawa do współistnienia węzła małżeńskiego z innymi sytuacjami współżycia intymnego $\mathrm{z}$ osobami trzecimi, społecznie uznanymi i będącymi źródłem obowiązków prawnych w relacji do tych osób ${ }^{14}$. Wola konkubencka jest zatem wykluczeniem jedności węzła małżeńskiego, a w konsekwencji wykluczeniem jedności współżycia. Jakkolwiek jedność węzła (unitas vinculi) i jedność współżycia (unitas copulae) nie są tym samym, jednak w rozumieniu doktryny i jurisprudencji utożsamiającej dobro wierności z jednością węzła jedność współżycia zawiera się właśnie w jedności węzła. Słusznie zatem zauważa W. Góralski, iż wykluczenie jedności współżycia, zawarte w wykluczeniu jedności węzła małżeńskiego, zachodzi wtedy, gdy w grę wchodzi udział w prawie do ciała (participatio iuris corpus), tzn. gdy samo prawo do ciała (ius in corpus) zostaje udzielona również jakiejś osobie trzeciej tak samo jak osobie współmałżonka. Podobnie dzieje się, gdy osoba zawierająca małżeństwo udziela wyłącznego prawa do ciała łącznie wielu osobom poza prawowitym małżonkiem ${ }^{15}$. Tak czytamy np. w sentencji coram Pinna z 14 kwietnia 1962 r. $^{16}$.

\footnotetext{
${ }^{13}$ Por. Sent. coram Felici z 24.01.1951 r., RRD 43, 1951, s. 51. Czytamy tutaj: „Excludit autem unitatem, uti legitimus in alia S.R.R., Nullitatis Matrimonii, diei 20 maii 1930, coram Quattrocolo, "qui in matrimonii celebratione intendat, praeter traditionem et acceptationem iuris ad actus coniugales cum altero contrahente, etiam ius aut obligationem ad actus coniugales cum tertia persona» (dec. XXII, 24, 6): nisi nempe qui iura dividere praesumit ita ut, si sit vir, plures quasi uxores (poligynia), si sit mulier, plures quasi viros (polyandria) sibi copulare velit, etsi in actu celebrationis matrimonii unam tantum mulierem, vel respective unum tantum virum, sibi coniugere videatur".

${ }^{14}$ Por. P. J. Viladrich, dz. cyt., s. 329-330.

${ }^{15}$ Por. W. Góralski, Kanoniczna zgoda małżeńska, Gdańsk 1991, s. 172-173.

${ }^{16}$ Por. Sent. coram Pinna z 14.04.1962 r., RRD 54, 1962, s. 151. Czytamy tutaj: „Si quis ergo positivo voluntatis actu alteri coniugi ius exclusivum non tradit, sed
} 
Prawo, o którym mowa tylko wówczas pozbawione jest przymiotu wyłączności, czytamy w sentencji coram Rogers z 20 grudnia 1965 r., gdy kontrahent zamierza dzielić na równi z wieloma osobami prawo do aktów o charakterze małżeńskim ${ }^{17}$. Podkreślają to sentencje: coram Canestri z 15 lipca $1941 \mathrm{r}^{18}$, jak i coram Wynen z 17 lipca 1950 r. ${ }^{19}$.

Wola konkubencka opiera się zatem na woli stworzenia relacji o charakterze małżeńskim, czy raczej pseudomałżeńskim z osobą, czy osobami trzecimi, gdyż, jak zauważa C. Burke, zawarcie małżeństwa z jedną osobą wyklucza możliwość stworzenia jednakowo małżeńskiej relacji z inną osobą. Jakkolwiek owa nowa relacja, która staje się dla kontrahenta celem wykluczenia wyłącznego prawa współmałonka do aktów o charakterze małżeńskim, ma charakter bardziej pseudomałżeński, niż małżeński, intencja tegoż kontrahenta polega na nadaniu jej charakteru małżeńskiego ${ }^{20}$.

\section{Dowody}

Pośród różnych okoliczności wskazanych w art. $14 \$ 1$ Ratio procedenti wymienia się te, które w moim przekonaniu dotyczą omawianego przypadku wykluczenia jedności małżeńskiej. Należy do nich

cumulativum cum alii quoque, seu non uni comparti, sed tertiae cuidam personae vel pluribus amasiis ius tradend intendat, cum consensum limitet validium matrimonium non contrahit [...]. Unitatem respuendo, quae est matrimonii essentialis proprietas (can. $1013 \$ 2$ ), aliquid de essentia ipsa coniugii detrahitur, sine quo sacrum foedus nuptiarum consistere nequit".

${ }^{17}$ Por. Sent. coram Rogers z 20.12.1965 r., RRD 57, 1965, s. 967.

${ }^{18}$ Por. Sent. coram Canestri z 15.07.1941 r., RRD 33, 1941, s. 622. Czytamy tutaj: „Bonum fidei, circa quod communiter deprehenduntur errores in conceptu, dest tantummodo cum saltem unus ex contrahentibus, in matrimonii celebratione, intendit, praeter traditionem et acceptationem iuris ad actus coniugales cum altero contrahente, etiam ius aut obligationem ad actus coniugales cum tertia persona".

${ }^{19}$ Por. Sent. coram Wynen z 17.07.1950 r., RRD 42, 1950, s. 383. Czytamy tutaj: „Ad dirimendum matrimonium ex hoc capite requiritur potius ut contrahens in celebratione matrimonii, actualiter vel virtualiter, positivo voluntatis actu, demat de suo consensu, sive totaliter sive saltem partialiter, ipsum ius uni et soli comparti competens, tradendo hoc ius, totum vel ex parte, alizui tertia persona [...]".

${ }^{20}$ Por. C. Burke, Il contenuto del «bonum fidei», Apollinaris 64, 1991, s. 651. 
zaliczyć dwie okoliczności: krótki okres pożycia małżeńskiego oraz uporczywe pozostawanie w relacji pozamałżeńskiej w czasie zawierania małżeństwa lub wkrótce po zawarciu małżeństwa. W szczególności ta druga okoliczność ma duży walor dowodowy. Jakie zatem dowody należy przedstawić w przypadku procesu skróconego prowadzonego z tytułu wykluczenia jedności małżeńskiej?

Dowodzenie nie należy do łatwych. Trzeba, bowiem, wykazać, iż miał miejsce pozytywny akt woli poprzez który została wykluczona jedność i to w aspekcie ipsum ius w momencie zawierania małżeństwa ${ }^{21}$.

Pozytywny akt woli, przynależący do rzeczywistości czysto psychologicznej ludzkiego działania, w zasadzie pozostaje w sferze wewnętrznej, często skrywając się za innym aktem, przez co jego rzeczywiste dostrzeżenie jest bardzo trudne. Bardzo często, sama osoba dokonująca symulacji nie jest w stanie rozróżnić prawdziwej symulacji od pragnienia jako takiego, opinię od działania. Stąd, rola sędziego w podejmowaniu decyzji dotyczącej symulacji nie jest łatwa, zwłaszca że trudno jest określić jednoznaczne reguły dotyczące wszystkich przypadków symulacyjnych. Jak się wydaje, każdy z nich jest odmienny i posiadający charakter szczególności.

Przekonujące o wykluczeniu jedności małżeńskiej jest confessio iudicialis. Confessio czyli przyznanie, jest to stwierdzenie jakiegoś faktu, na piśmie lub ustnie, dokonane przeciwko sobie przez którąś ze stron co do samego przedmiotu sprawy. Zatem, elementem charakteryzującym confessio jest tzw. animus confitendi, czyli świadomość dążenia do ukazania prawdy nawet za ceną pogorszenia swojej pozycji w procesie.

Przepisy zawarte w Mitis Iudex Dominus Iesus Ojca Świętego Franciszka nie zmieniają rozumienia środka dowodowego, jakim jest confessio iudicialis, ani też nie dokonują zmian co do jej stosowania

\footnotetext{
${ }^{21}$ Por. W. GóR ALski, Proces małżeński skrócony przed biskupem, Płock 2017, s. 85. Autor swoje spostrzeżenie odnosi do wykluczenia wierności, ale moim zdaniem ma ono zastosowanie również do wykluczenia jedności małżeńskiej.
} 
$\mathrm{w}$ aspekcie proceduralnym ${ }^{22}$. Wprowadzają natomiast istotną zmianę co do jej wartości dowodowej w procesie o stwierdzenie nieważności małżeństwa czy, jak określa to T. Rozkrut, uściślają walor dowodowy sądowego przyznania się i oświadczeń stron procesowych ${ }^{23}$. Zgodnie bowiem, z kan. $1678 \$ 1$ Mitis Iudex Dominus Iesus w sprawach o nieważność małżeństwa przyznanie się sądowe oraz oświadczenia stron, poparte ewentualnymi zeznaniami świadków potwierdzającymi ich wiarygodność, mogą mieć pełną wartość dowodową, którą winien ocenić sędzia, po dokładnym rozważeniu wszystkich wskazówek i poszlak, chyba że pojawiają się inne elementy, które je obalają.

Należy zatem zauważyć, że zarówno przyznanie się sądowe, jak i inne oświadczenia stron mogą mieć wartość dowodu pełnego. Ma to niezwykłe znaczenie w odniesieniu do procesu biskupiego gdyż przyznanie się sądowe może stanowić wystarczający dowód do orzeczenia nieważności małżeństwa na jednym posiedzeniu trybunału, po spełnieniu określonych warunków, zgodnie z procedurą procesu skróconego.

W świetle Mitis Iudex Dominus Iesus zeznania świadków potwierdzających wiarygodność strony powodowej lub pozwanej nabierają zupełnie nowego wymiaru ${ }^{24}$. Potwierdzenie, bowiem, wiarygodności strony przez zeznających w procesie świadków jest elementem wystarczającym do nadania przyznaniu się sądowemu lub innemu oświadczeniu strony mocy dowodu pełnego. Co więcej, jak zauważa J. Krajczyński, sędzia może podważyć wartość dowodową oświadczeń i przyznania się sądowego tylko wtedy, gdy w aktach sprawy znajdzie przynajmniej jedną racjonalną przesłankę, która wskazuje na brak wiarygodności stron ${ }^{25}$. Istotna rola przyznana przez Prawodawcę

\footnotetext{
${ }^{22}$ Por. G. Leszczyński, Wartość dowodowa confessio iudicialis w świetle Mitis iudex Dominus Iesus papieża Franiciszka, Prawo Kanoniczne 58(2015) nr 4, s. 130-131.

${ }^{23}$ Por. T. Rozkrut, Wprowadzenie i instrukcja sprawy, w: Praktyczny komentarz do Listu apostolskiego motu proprio Mitis Iudex Dominus Iesus papieża Franciszka, Tarnów 2015, s. 107.

${ }^{24}$ Por. G. Leszczyński, Wartość..., dz. cyt., s. 132-133.

${ }^{25}$ Por. J. Krajczyński, Proces zwyczajny, w: Proces małżeński według motu proprio Mitis Iudex Dominus Iesus, Płock 2015, s. 71.
} 
zeznaniom świadków stawia przed sędzią konieczność rzetelnej oceny wiarygodności samych świadków. W tym względzie, jak się wydaje, sędzia dokonując oceny merytorycznej zeznań świadków, winien też ocenić ich wiarygodność czyli stan osoby i jej uczciwość. Dlatego też Prawodawca w kan. 1572 KPK przewiduje możliwość zażądania przez sędziego świadectwa kwalifikacyjnego. Zdaniem J. J. García Failde, takowe świadectwo może pomóc sędziemu w poznaniu sposobu życia, jak również zaangażowania religijnego świadka, co może mieć znaczenie w odniesieniu do obowiązku mówienia prawdy w procesie kościelnym. Ten sam autor jednak podkreśla, że nie należy przeceniać relacji zachodzącej między stylem życia, a mówieniem prawdy, gdyż relacja ta nie zawsze jest jednoznaczna ${ }^{26}$. Zdarzają się bowiem świadkowie, którzy pomimo dobrej opinii zeznają nieprawdę zeznając w przeświadczeniu konieczności udzielenia pomocy stronie, niezależnie od prawdy faktycznej ${ }^{27}$. Nie można też wykluczyć, że zeznania świadków są ukształtowane przez same strony, którym zależy na potwierdzeniu przedstawionych przez nie tez ${ }^{28}$.

Zeznania świadków, jak już zostało to zauważone, mogą odegrać istotną rolę w kształtowaniu pewności moralnej sędziego w sytuacji, gdy strona, która wykluczyła ze swojego małżeństwa jedność małżeńską, nie przyznaje się w sądzie do tego, a przeciwnie stara się zakryć prawdziwe fakty chcąc zemścić się na współmałżonku. Nie tylko jednak w takich okolicznościach zeznania świadków mają istotną wartość. Podobnie jest wówczas, gdy strona symulująca nie uczestniczy w procesie, jak i wtedy gdy przyznaje się sądownie, czy też przyznała się pozasądowo do popełnionego czynu. Zeznania świadków

\footnotetext{
${ }^{26}$ Por. J. J. García FAilde, Nuevo derecho procesal canonico, Salamanca 1984, s. 140. Autor zauważa: „Ha de tenerse muy en cuenta la veracidad de la que dé muestras el testigo. Para ello es importante conocer su modo de ser, sus costumbres, su religiosidad práctica, etc. Pero no debe exagerarse hasta el extremo de establecer una correlación poco menos que necesaria entre buenas / malas costumbres, etc., y veracidad / no veracidad del testigo: personas hay que, a pesar de sus malas costumbres ..., son veraces y que, no obstante sus buenas costumbres..., no son veraces".

${ }^{27}$ Por. Sent. coram De Laversin, 10.11.1992, RRD 84, 1992, s. 546.

${ }^{28}$ Por. Sent. coram Stankiewicz, 17.12.1993, RRD 85, 1993, s. 783.
} 
z pewnością pomagają zrozumieć nie tylko osobowość symulanta, ale również samą przyczynę wykluczenia jedności małżeńskiej.

\section{Causa simulandi}

Istnieją pewne motywy, korzyści i subiektywne cele, które w zjawisku symulacji uprzedzają pozytywny akt woli wykluczający jedność małżeńską. Dla celów dowodowych, jak słusznie zauważa P. J. Viladrich, są one bardzo ważne, ponieważ, choć same w sobie nie są pozytywnym aktem wykluczenia, niemniej wyjaśniają scenerię biograficzną, która w sposób rozumny pozwala zakładać, możliwość zaistnienia pozytywnego aktu wykluczenia. Motywacje te jednak mogą wpłynąć na kontrahenta albo w sposób pozytywny, stając się przyczyną zawarcia małżeństwa (causa celebrandi), albo w sposób negatywny, stając się przyczyną wykluczenia jedności małżeńskiej (causa simulandi) $^{29}$. I tak ta sama motywacja, jaką jest np. uczuciowy związek z kochanką, może pobudzać do prawdziwego małżeństwa, ponieważ kontrahent uważa, że jego nowy stan małżeński posłuży mu jako możliwość zerwania więzów łączących go z inną osobą, może jednak stać się przyczyną symulacji, gdyż kontrahent wykluczy prawo swojej współmałżonki do wyłączności aktów seksualnych, z racji na istniejacą pseudomałżeńską relację $\mathrm{z}$ inną osobą ${ }^{30}$.

Przyczyna symulacji zatem różni się od przyczyny zawarcia małżeństwa ${ }^{31}$, gdyż musi być od niej silniejsza ${ }^{32}$. Przyczyna symulacji

\footnotetext{
${ }^{29}$ Por. Sent. coram Ewers z 19.04.1972 r., RRD 64, 1972, s. 181. Czytamy tutaj: „Quapropter confundenda non est simulationis causa cum motivis quae aliquem ad contrahendum induxerunt: 'haec enim optime stare possunt cum vero matrimonio, immo plerumque dant causam contractui, uti sunt libertatem ope coniugii consequi, etc., dummodo praevalentem consensum in nuptiis comitentur et illum non excludant' [...]. Denique, una eademque causa nequit motivum praebere ad contrahendum et simul ad simulandum, cum sibi invicem haec contradicant et ideo ex eadem causa oriri non possint”.

${ }^{30}$ Por. P. J. Viladrich, Konsens..., dz. cyt., s. 271-272.

${ }^{31}$ Por. Sent. coram De Laversin z 10.11.1992 r., RRD 84, 1992, s. 540.

${ }^{32}$ Por. Sent. coram Ewers z 19.04.1972 r., RRD 64, 1972, s. 180. Czytamy tutaj: „Causa simulationis autem est ratio qua quis matrimonium contrahere positive
} 
musi być nie tylko wystarczajaco poważna, ale przede wszystkim proporcjonalna w odniesieniu do przedmiotu wykluczenia, czyli przymiotu jedności małżeńskiej ${ }^{33}$. Wskazując na konkretne przymioty, jakie powinna mieć przyczyna symulacji, sentencja coram Bruno z 17 maja 1996 r. mówi, że powinna być ona jasna, pewna, obiektywna lub przynajmiej subiektywnie ciężka oraz, co już zaznaczyliśmy, przeważająca nad przyczyną zawarcia małżeństwa ${ }^{34}$. Oceniając zatem każdy przypadek sędzia winien porównać obie przyczyny upewniając się, że causa simulandi przeważyła wolę zawarcia małżeństwa ${ }^{35}$.

Zagadnienie relacji zachodzącej między przyczyną zawarcia małżeństwa a przyczyną wykluczenia jedności małżeńskiej związane jest z określeniem intencji przeważającej przy wyrażaniu przez kontrahenta zgody małżeńskiej. Nie idzie o obecność dwóch aktów woli ${ }^{36}$, ale raczej o wskazanie, jak słusznie stwierdza Sabattani w wyroku z 13 listopada 1959 r., czy w momencie wyrażania zgody małżeńskiej, w ocenie kontrahenta, większe znaczenie odgrywały przyczyny zawarcia małżeństwa czyli causa celebrandi albo contrahendi, czy też przyczyna symulacji, inaczej causa simulandi ${ }^{37}$. Istotne jest bowiem,

nolens aut non ita seu essentialibus qualitatibus non praeditum, tamen inductus fuerit ad proferendum ore quod corde non teneret".

${ }^{33}$ Por. Sent. coram Pompedda z 21.01.1972 r., RRD 64, 1972, s. 26.

${ }^{34}$ Por. Sent. coram Bruno z 17.05.1996 r., RRD 88, 1996, s. 389.

${ }^{35}$ Por. Sent. coram Bruno z 12.03.1993 r., RRD 85, 1993, s. 146; L. Świto, Exclusio boni prolis jako tytuł nieważności małżeństwa, Olsztyn 2003, s. 95.

${ }^{36}$ Por. L. De Luca, L'esclusione del "bonum coniugum», w: La simulazione del consenso matrimoniale canonico, Città del Vaticano 1990, s. 137. Czytamy tutaj: „E' noto che la dottrina e la giurisprudenza canonistica sono solite distinguere nei casi della c.d. simulazione due atti di volontà: la voluntas matrimonium celebrandi e la voluntas simulandi, le quali volontà a loro volta presupporrebbero due distinte "causae». Ora, tale distinzione tra le due volontà è puramente teorica, giacché la stessa dottrina e la giurisprudenza canonistiche finiscono per dover riconoscere che la nullità del matrimonio si verifica quando la volontà contraria alla «substantia matrimonii» non si accompagnata soltanto alla «voluntas matrimonialis». Ma "penetri» in essa giacché solo in questo caso se ne produce la distruzione".

${ }^{37}$ Por. Sent. coram Sabattani z 13.11.1959 r., RRD 51, 1959, s. 503. Czytamy tutaj: „Inquirendum est ideo utrum matrimonium in sua substantia vitiatum revera 
jak stwierdza sentencja coram Funghini z 23 października 1991 r., należyte poznanie, jaka była w momencie zawierania małżeństwa intentio praevalens kontrahenta ${ }^{38}$.

Przyczyna bliższa trudna jest do sprecyzowania, gdyż ile jest przypadków dotyczących wykluczenia jedności małżeńskiej, tyle może też być konkretnych przyczyn, które w danym momencie wyrażania zgody małżeńskiej kierują wolą symulacyjną kontrahenta. Najbardziej prawdopodobną przyczyną bliższą i z pewnością najczęściej spotykaną jest istniejacy związek z osobą, którą kontrahent, pomimo zawierania małżeństwa, nie chce porzucić ${ }^{39}$. Podobnie przyczyną bliższą wykluczenia jedności małżeńskiej może stać się, jak z kolei czytamy w sentencji coram Mercieca z 16 grudnia 1972 r., awersja do osoby współkontrahenta, czy też do samego małżeństwa ${ }^{40}$.

Przyczyna dalsza tkwi albo w zaburzeniach osobowości kontrahenta ${ }^{41}$, albo w samej kulturze wolnościowej, która tak wpływa na wolę kontrahenta, że popycha do zawarcia małżeństwa z zastrzeżeniem sobie prawa do prowadzenia życia otwartego, wolnego, niezwiązanego obowiązkiem wyłącznosci ${ }^{42}$. Do głównych zaburzeń osobowości, które mogą stanowić przyczynę wykluczenia jedności orzecznictwo, w różnym wymiarze na przestrzeni lat, zaliczało anomalie psychoseksualne, takie jak homoseksualizm ${ }^{43}$, ninfomanię czy satyryzm $^{44}$. Wydaje się jednak, że przyczyna wykluczenia jedności małżeńskiej z dzisiejszej perspektywy nie znajduje się w zaburzeniach psychoseksualnych kontrahenta, ale raczej w ogólnie pojętej

praevaluerit, et quidem per positivam intentionem, utrum in aestimatione nupturientis maius momentum habuerint causae contrahendi an simulandi [...]".

${ }^{38}$ Por. Sent. coram Funghini z 23.10.1991 r., RRD 83, 1991, s. 607.

${ }^{39}$ Por. Sent. coram Bruno z 15.06.1990 r., RRD 82, 1990, s. 516-517.

${ }^{40}$ Por. Sent. coram Mercieca z 16.12.1972 r., RRD 64, 1972, s. 785.

${ }^{41}$ Por. sent. coram Bruno z 24.07.1985 r., RRD 77, 1985, s. 407.

${ }^{42}$ Por. Sent. coram Bruno z 15.06.1990 r., RRD 82, 1990, s. 516-517.

${ }^{43}$ Por. G. Dzierżon, Niezdolność do zawarcia małżeństwa jako kategoria kanoniczna, Warszawa 2002, s. 177-181.

${ }^{44}$ Por. S. PAźDzIor, Przyczyny psychiczne niezdolności osoby do zawarcia małżenstwa $w$ świetle kan. 1095, Lublin 1999, s. 265. 
osobowości, ukształtowanej w kulturze wolności seksualnej, która objawia się ogólną deprawacją moralną człowieka, która może osiągać stadia perwersyjne ${ }^{45}$.

Osobowość zdeprawowana, którą orzecznictwo określa czasem terminem perwersyjna oznacza osobowość ukształtowaną we współczesnym społeczeństwie, otwartym na jakąkolwiek formę miłości, wolną w swoim wyrazie i zachowaniu ${ }^{46}$. Jak czytamy w wyroku coram Ragni z 9 grudnia 1982 r., współczesne społeczeństwo zatraciło poczucie wyłączności małżonków i trwałości związku małżeńskiego. Ponadto obraz wierności, a także małżeństwa, kształtowany przez media nie ma wiele wspólnego z doktryną Kościoła, przedstawiającą małżeństwo jako związek trwały i wyłączny. Obraz kobiety, eksponowany w tychże mediach, nie koncentruje się na jej godności, ale wręcz przeciwnie przedstawia ją jako obiekt erotycznych pragnień i nieetycznych zachowań ${ }^{47}$. Takie postrzeganie kobiety z pewnością nie sprzyja kształtowaniu właściwego rozumienia obowiązku wyłączności, jedności i wierności, i co więcej, formuje osobowość współczesnego człowieka otwartą na przeżywanie swojej seksualności w sposób wolny, czasem nawet zdeprawowany ${ }^{48}$.

\footnotetext{
${ }^{45}$ Por. Sent. coram Colagiovanni z 15.10 .1980 r., RRD 72, 1980, s. 650.

${ }^{46}$ Por. Sent. coram Stankiewicz z 14.11.1985 r., RRD 85, 1985, s. 486.

${ }^{47}$ Por. Sent. coram Ragni z 9.12.1982 r., RRD 74, 1982, s. 596. Czytamy tutaj: „Praeterea, series quotidiana facinorum sexualium quae media communicationum socialium offerunt praesertim uti vilipendium matrimonialium obligationum, plane demonstrat quam erroneam ac damnosam esse opinionem circa mulierem, obiectum (non subiectum) iuris consideratam, seu obiectum libidinis factam, rem eroticam tantum pictam, i. e. dignitate humana omnino orbatam. Neque omitti potest inquirere quo mentis ac voluntatis habitu, ex tam prava schola sociali, imbutus exstet circa perpetuitatem ac exclusivitatem iuris coniugalis iuvenis qui ad nuptias contrahendas accedit, si, olim baptizatus, rectam doctrinam ac praxim christianam secutus non sit et asseclam fuisse immoralium et amoralium dictaminum de quibus supra, imminentibus nuptiis ac immediate postea qualificetur, uti inferius videbimus".

${ }^{48}$ Por. Sent. coram Ferrao z 16.10.1984 r., RRD 76, 1984, s. 526; sent. coram Bruno z 24.07.1985 r., RRD 77, 1985, s. 407; sent. coram Davino z 24.01.1991 r., RRD 83, 1991, s. 40 .
} 


\section{Wnioski}

Właściwa ocena faktów, dokonana przez biskupa diecezjalnego, pozwala mu w podjęciu decyzji co do stwierzdenia nieważności małżeństwa bądź skierowania akt do przeprowadzenia procesu zwykłego. Z pewnością, oprócz wyżej wskazanych dowodów pomocą biskupowi posłużą również domniemania wypracowane przez orzecznictwo.

Orzecznictwo na przestrzeni lat wypracowało domniemania pozwalające zrozumieć prawdziwą wolę kontrahenta w momencie wyrażania przez niego aktu zgody małżeńskiej ${ }^{49}$. Ważnym kryterium jest z pewnoscią intentio praevalens, pozwalające zrozumieć, czy kontrahent zawierając małżeństwo w istocie chciał je zawrzeć zgodnie $z$ jego integralnym rozumieniem, czy też pozytywnym aktem woli wykluczył z niego jedność małżeńską ${ }^{50}$. Ważnym domniemaniem wypracowanym przez jurisprudencję jest odniesienie popełnianego okazjonalnie cudzołóstwa do rzeczywistego wykluczenia jedności małżeńskiej. Stwierdza ono, że niewierności mające miejsce po zawarciu małżeństwa, choćby były częste, nie stanowią dowodu wykluczenia prawa do wyłączności aktów małżeńskich, a stanowią jedynie nadużycie tegoż prawa przekazanego współmałżonkowi w momencie zawierania związku małżeńskiego. Oznacza to, że jeśli nawet ktoś popełnia cudzołóstwo uznaje zarówno przymiot jedności węzła małżenskiego, jak i obowiązek wierności małżeńskiej, a jedynie wskutek własnej słabości, nieodpowiedniego wychowania, wpływu kultury wolnych związków, nie respektuje faktycznie obowiązku, który podją ${ }^{51}$. Jak słusznie zauważa P. Bianchi jest to jedynie domniemanie zwykłe, które dopuszcza dowód przeciwny, co oznacza że jeśli zgromadzony materiał dowodowy byłby w stanie je obalić, mielibyśmy do czynienia z udowodnieniem wykluczenia prawa do wyłączności aktów małżeńskich, a nie jedynie niedotrzymania podjętego obowiązku.

\footnotetext{
${ }^{49}$ Por. Sent. coram Ewers z 11.10.1969 r., RRD 61, 1969, s. 941.

${ }^{50}$ Por. Sent. coram Funghini z 23.10.1991 r., RRD 83, 1991, s. 607.

${ }^{51}$ Por. Sent. coram De Laversin z 17.03.1982 r., RRD 74, 1982, s. 119.
} 
Inne ważne domniemanie stwierdza, że utrzymywanie relacji pozamałżenskiej z osobą, z którą kontrahent był związany przed zawarciem małżeństwa może być dowodem wykluczenia przymiotu jedności węzła małżeńskiego ${ }^{52}$. Niektórzy ponensi jako domniemanie potwierdzające wykluczenie jedności wskazują współczesną mentalność przeciwną doktrynie Kościoła dotyczącej małżeństwa ${ }^{53}$.

Domniemania sędziowskie sformułowane na podstawie faktów pewnych i określonych, w opraciu o domniemanie istniejące w jurisprudencji, pozwalają biskupowi nabyć tej pewności moralnej, która konieczna jest do wydania wyroku. Jakkolwiek owe fakty nie zawsze mogą być interpretowane w sposób jednoznaczny, pozwalają z pewnością określić prawdziwą intencję zawarcia małżeństwa w odniesieniu do przymiotu, jakim jest jedność małżeńska. Wszystkie środki dowodowe, które staraliśmy się wskazać mają bowiem za zadanie ukazanie prawdziwej intencji kontrahenta, który w momecnie wyrażania zgody małżeńskiej wyklucza prawo współmałżonka do wyłączności węzła małżeńskiego.

\section{The exclusion of marriage unity as a case of marriage nullity in the bishop process}

Taking up the value of confessio iudicialis and the other proofs for declaring a marriage null and voit in the short bishop process, the author begins his reflections with a look at one of the marriage property that is marriage unity. From the point of view of marriage validity, of special significance is also the analysis of confessio iudicialis and testimonies in the Code of Canon Law from 1983. The last part of the author's reflections is devoted to the analysis of judge presumptions and causes of simulation of marriage, according to Pope's Francis Mitis Iudex Dominus Iesus.

SŁoWA KLUCZOWE: małżeństwo; dowody; jedność; proces biskupi

\footnotetext{
${ }^{52}$ Por. Sent. coram Pompedda z 19.12.1970 r., RRD 62, 1970, s. 1189; sent. coram Colagiovanni z 15.10.1980 r., RRD 72, 1980, s. 650; sent. coram Palestro z 16.05.1990 r., RRD 82, s. 371.

${ }^{53}$ Por. Sent. coram Palestro z 16.05.1990 r., RRD 82, 1990, s. 370.
} 
KEY WORDS: marriage; proofs; unity; bishop proces

\section{Nota o Autorze:}

Ks. PROF. DR HAB. GRZEgorz LESzCZYŃSKi - profesor zwyczajny na Wydziale Prawa i Administracji Uniwersytetu Łódzkiego, Oficjał Trybunału Metropolitalnego Łódzkiego. 